\title{
Bodily Representations of the Shame of Inferiority in Sofi Oksanen's Novels
}

\author{
Krisztina Karizs ${ }^{1}$ - Laura Bába \\ Department of Hungarian Studies, Hankuk University of Foreign Studies, Seoul - Department of \\ Finno-Ugric Studies, Eötvös Loránd University, Budapest
}

\begin{abstract}
The range of violence comprises severe physical abuse and different methods of mental torture as well as social discrimination. Beside the traumas themselves, these acts also burden the victims with shame. Finnish writer Sofi Oksanen (born 1977) discusses these issues in her works. As a writer, Oksanen is very sensitive to social issues, discrimination and the unfairness of history. Most of her characters suffer from the shame of inferiority caused by physical or mental violence. Oksanen analyzes the influence of shame in our lives, and her characters demonstrate several different responses to the feeling.

Eyesight and our looks play an important role in recognizing or hiding the humiliating episodes of our past. Appearance often reflects all our inner struggles and represents our mental state, wherefore a given individual's manner of personal care and habits of shaping the body reveal a great deal about the person. Personal and beauty care come up in different ways in Oksanen's novels and have varying symbolic meanings, but they have at least one thing in common: they are related to creating a false identity, one which is more acceptable for those in the surrounding environment.

This paper analyzes the mechanism of shame connected to the feeling of inferiority, concentrating on four of Oksanen's novels (Stalin's Cows, Baby Jane, Purge and When the Doves Disappeared). Although violence can lead to mental disorders and the shame of inferiority also belongs to the domain of emotions, the paper focuses on the physical consequences of the victims' mental state, which can vary from severe physical disorders to everyday personal grooming or beauty care.
\end{abstract}

Keywords: violence, shame, identity, body, cleanliness, hygiene

${ }^{1}$ This work was supported by Hankuk University of Foreign Studies Research Fund of 2016. 


\section{INTRODUCTION}

It is impossible to discuss contemporary Nordic literature without mentioning the young Finnish-Estonian writer Sofi Oksanen, presumably the best-known contemporary Finnish author worldwide. Oksanen was born in 1977 in Jyväskylä, Finland. Her father married an Estonian woman while he was working in Tallinn, thus she is well aware of the culture and history of both countries. Oksanen graduated from the University of Jyväskylä and also attended drama classes at the Finnish Theatre Academy in Helsinki. She has become a prominent figure in Finnish publishing, and she established her own publishing company in 2011. Oksanen has received several honorable prizes both in Finland and abroad, and she delivered one of the opening speeches at the Frankfurt Book Fair in 2014, where Finland was the guest of honour country.

As a writer, Oksanen is very sensitive to social issues, discrimination and the unfairness of history. She has published five novels in the last ten years based on these issues. She is known internationally for her successful Quartet series. The first novel of the series, Stalin's Cows, was published in 2003 (OKsanen 2003). The narrator of the book inherits the feeling of inferiority and shame from her mother, and develops an eating disorder as a method of purification. She also uses her perfect body to hide her true identity behind the image of the modern western woman.

Oksanen's breakthrough came with the second part of the series Purge, which was first published as a play, but was extended into a novel in 2008 (OKSANEN 2008). Since then, it has been translated into more than 40 languages ${ }^{2}$ and the original drama version of the novel has also been staged in various countries, including Hungary. Purge describes the fate of two women in two different eras, and raises important questions about violence against women and unprocessed historical traumas. Unlike the first two novels, in the next part of the series, When the Doves Disappeared (OKsanen 2012, 2015a), Oksanen chooses an opportunist man as the main character and analyzes how officially accepted historical lies are created under oppression. In her latest novel, Norma (OKSANEN 2015b) Oksanen returns to the tradition of Stalin's Cows and Purge in that she again chooses a woman as her protagonist, but the book does not belong to the Quartet series. Before the huge success of Purge in 2005, Oksanen published another novel called Baby Jane (OKSANEN 2005), which deals with homosexual subculture in Helsinki and the fate of people with mental illnesses. The novel also criticizes the attitude of medical service and its absolute inability to help.

Oksanen's point of view in the Quartet series is very unique, becaue she doesn't write about Finland but turns her attention to Soviet Estonia. She focuses mostly on people behind the frontlines, and analyzes what kind of influence war and its violence have on their everyday lives. Moreover, she is interested in the children of this war generation, and demonstrates the consequences of historical trauma, not only from the vantage point of the lives of the people who suffered from it, but also by considering the struggles of their descendants.

\footnotetext{
${ }^{2}$ First English edition by Lola Rogers (OKSANEN 2010).
} 
This paper analyzes the mechanism of shame connected to the feeling of inferiority, a very common consequence of violence. It concentrates on the first three novels of the Quartet series and on Baby Jane, and points out how the characters react to the shame of inferiority. Although violence usually leads to certain mental disorders and the shame of inferiority is also in the domain of feelings, this article focuses on the physical consequences of the victims' mental state, which can vary from severe physical disorders to the average behaviours of hygiene or beauty care.

\section{THE DEFINITION OF SHAME}

This article uses Silvan S. Tomkins' definition of shame. Tomkins describes shame as an affect auxiliary, and defines affects as "sets of muscular, glandular, and skin receptor responses located in the face (and also widely distributed throughout the body) that generate sensory feedback to a system that finds them either inherently 'acceptable' or "unacceptable" (TOMKINs 1987:137). According to his research on the affect mechanism, these physical responses in humans are caused by various triggers, which can vary widely depending on someone's family or cultural background and personality. The way we are raised and the norms that we espouse from society have a strong influence on our representations of the world, and they make us sensitive to various effects coming from the outside. It follows that the events triggering the affects can be very diverse. However, the physical responses given to them are biologically coded, and therefore these are the same in the case of every human being (TomKINs 1987:134-145).

In his studies, Tomkins distinguishes positive affects, such as interest, joy and surprise, and negative ones, which are distress, fear, disgust, anger and shame. His list contains primary and secondary responses from which shame is characterized as an affect auxiliary that "operates only after interest or enjoyment is activated" (ToMKINS 1987:144). In other words, shame is awakened by the incomplete reduction of interest, and it is always followed by the fear of being exposed. Besides its biological nature, shame also has a social aspect, which helps to understand the reasons for this fear. As human beings, we want to be part of a group and be accepted by its members. We long for attention and the interest of others, thus the reduction of this interest gives us a very strong and clearly negative judgement about ourselves. As a result of being revealed, we can be discriminated against by the group we wish to belong to. Since the responses of shame are very easily recognizable, this mechanism can become a perfect tool of control. The person who humiliates someone can also control the victim's life and actions because he or she will do anything to avoid being exposed and, as a result, being discriminated against. Shame has been used for controlling others for a long time, and in many fields of life, such as in the extreme conditions of war or in the dynamics of relationships.

Australian scholar Elspeth Probyn, who currently works at the University of Sidney as a professor of Gender and Cultural Studies, follows Tomkins' ideas in her works, but also goes one step further. She differentiates a positive and a negative version of shame. According to Probyn, when shame only gives us feedback on our behaviour, it can help us improve ourselves. However, in most cases we experience a negative shame, which is always connected to the feeling of inferiority. Although shame itself never changes its nature or evolves into something other than the physical response to 
the affect, victims usually embody the feeling of inferiority, which becomes a part of their identities (ProbYN 2005:IX-XVII). As a result, the automatic responses given to shame and the fear of being exposed slowly turn into bodily habits, such as unintended movements, various disorders or special body care practices.

\section{BODILY REPRESENTATIONS OF THE SHAME OF INFERIORITY IN THE NOVELS}

The mechanism and the consequences of shame and fear are very important phenomena in Sofi Oksanen's work (LAPPALAINEN 2011:259-263). The main characters of her Quartet series almost always suffer from the shame of inferiority, which Probyn mentions in her research. Oksanen analyzes very minutely the most common responses to this shame through the behaviours of her protagonists. Humiliation has clear physical aspects in all of her novels, and the act which awakens shame and inferiority is always connected to the body. Therefore, not just the physical domain of affect mechanism but also Oksanen's point of view result in the representation of bodily responses to the feelings mentioned.

These reactions, as shown in the Quartet series and in Baby Jane, can be divided into three types, of which the first one immediately follows the act of humiliation and aims to purify the victim and erase the shame. The second and the third types are tightly connected and are the result of the fear of being exposed, which is attached to shame. All victims of humiliation try to hide from society and veil their habits connected to inferiority. At a higher level of hiding, the symptoms do not only concern bodily responses but also indicate an identity crisis and lead to drastic changes in someone's personality.

\section{ERASING SHAME - METHODS OF CLEANSING AND PURIFICATION}

The first part of the analysis tackles a list of reactions connected to the need of cleansing the body. The longing for purification appears most clearly in Purge, in which both women protagonists are the victims of sexual violence. The plot develops on two levels: between the 1930s and 1950s - the last years of the independent Estonia, the German invasion and the beginning of the Soviet era, and in 1991-92 - at the beginning of the new independence. The two storylines intertwine, and they are connected through Aliide's character. The other main character is Zara, Aliide's grandniece, who was born and raised in Vladivostok, where her mother and grandmother have been deported, and who turns up unknown to old Aliide's house.

The young Aliide Tamm had been humiliated and raped in the basement of the City Hall by Soviet soldiers during an interrogation, while Zara is the victim of the sextrade business - which got a boost in the Eastern European countries after the collapse of the Soviet Union (KLINGMAN - LimONCELLI 2005:118-143) - and was used as a prostitute by the mafia. In their cases, the process of cleansing is very tangible. During her interrogation, Aliide is lying on the floor and is dirtied by soldiers' urine and sperm. Zara escapes from the mafia through the Estonian countryside and gets literally filthy by the time she reaches Aliide's house. Both women try to erase the memory of their 
victimization and their shame by cleansing their bodies. They are both offered a bath by the person who realizes that they have been abused:

"The girl snatched the pants from Aliide, peeled off her stockings, pulled on the Marats, tore off her dress, slipped on Aliide's housdress in its place, and before Aliide could stop her, threw her dress and stockings into the stove. "[...]

"Zara, there is nothing to worry about."

The girl stood in front of the stove as if to shelter the burning clothes. The housedress was buttoned crooked.

"How about a bath? I'll put some water on to warm," Aliide said. "There's nothing to worry about." (OKSANEN 2011:27-28.)

Beside being a symbolic cleaning, this is also a literal washing: the oppressors violate the women's body not only by the rape but also by contaminating them with body fluids - sperm on Zara's face, urine over Aliide's body. ${ }^{3}$ As the Kapitánys claim (KaPITÁNY - KAPITÁNY 2009:42), degrading someone by contaminating their body is an ancient symbolic technique, going back to the hierarchy-creating role of cleanliness. In both Zara's and Aliide's case, the purifying effect of water is combined with that of fire: both women want to burn their clothes associated with the rape.

The episodes of having a bath and burning the clothes they wore at the time of the assault are beautiful representations of the old Finno-Ugric tradition, where fire and water are both elements of cleansing and purification.

Beside these scenes, Oksanen pictures the purifying power of fire in another context. Aliide, who is secretly in love with her brother-in-law, is deeply ashamed by the fact that Hans had chosen her sister, Ingel, instead of her. After Ingel and her daughter - the proof of the couple's happiness - are deported to Siberia, Aliide burns her sister's wedding blanket. By this act she wants to destroy the marriage itself, and also the scars that it caused her.

Another way of cleansing the body appears in the first novel of the series, Stalin's Cows. The main character is a young woman, Anna, who - as Oksanen herself - was born to an Estonian mother and a Finnish father. She inherits the feeling of inferiority from her mother, who is ashamed of her Estonian roots in the more developed and more independent Finnish society. Anna unconsciously struggles with her mother's shame, and she is constantly afraid of not being accepted in Finland in case the secret of her Estonian background is revealed. Because the origins of her feelings are hidden in her mother's past and have no connections to her life, at first she cannot identify the feeling of inferiority. However, she is very aware of the part of her identity which she has to hide or wipe out. In her case bulimia is the method of cleansing, and she uses vomiting to purify her body and remove the undesired parts of her identity.

\footnotetext{
${ }^{3}$ Oksanen has admitted in an interview that the novel's Finnish title Puhdistus ('cleaning') refers to Aliide's and Zara's attempt to wash away the violence they suffered (LuIG 2010). For an analysis of the different meanings of the novel's original title and those of its translations, see Päivi Lappalainen's article (LAPPALAINEN 2013:342).
} 


\section{REPRESENTATIONS OF HIDING - CONSEQUENCES OF THE FEAR OF BEING EXPOSED}

The analysis of the background of Anna's eating disorders leads us to the next part of this treatise and another response to shame. As mentioned above, an act of humiliation and the embodiment of the feeling of inferiority are always followed by the fear of being exposed. Therefore, hiding is a very logical reaction of the victims. In Stalin's Cows, Anna not only suffers from bulimia but she also has very severe anorexia. The desire to create a thinner and smaller body stems from the very strong need to be hidden from the eyes that want to see too much. Her symptoms get worse when her boyfriend tries to get to know her better and learn her secrets. Finally, his attempt leads to an even stricter diet and forms a strong need in Anna to get small enough so that no one will be able to see her anymore.

Although the act of hiding does appear in Stalin's Cows, the most representative symbols of this reaction can be found in Purge. As Tomkins mentions in his paper, the signs of shame appearing on the face are blushing and lack of eye contact (TomKINs 1987:139). Oksanen plays with the dynamics of making eye contact to describe the nature of the characters' shame. Neither of the victims of the soldiers' violence can look each other in the eye. The next passage from the novel shows very clearly that although Ingel and her daughter Linda had survived their years in the forced labour camps of Siberia, they keep hiding their glances from each other.

\footnotetext{
"Mother [Linda] touched Grandmother's [Ingel's] hands and brow and gave her some water and Validol, and she took them without looking at her, which wasn't unusual; Grandmother never looked at anyone, she always looked past them." (OKSANEN 2011:49.)
}

Linda always acts the same way towards her daughter, Zara, who figures out the reasons behind her mother's behaviour only after her victimization. When she escapes the mafia and looks for shelter in her great-aunt Aliide's house, whom she knows from her grandmother's stories, she is not able to look the old woman in the eyes. Zara is well aware of the fact that her clothing and conditions present an obvious picture about her past, and she does not want to see the recognition in Aliide's eyes, thus she avoids looking at her directly.

"Then her [Zara's] gaze moved back to her own lap, to her hands, stopped there, then slid up to the butt end of Aliide's scythe, but didn't go any higher, [...] She finally managed to get up, but still didn't look Aliide in the face." (OKSANEn 2011:11.)

In the case of Aliide, the dynamics of eye contact are even more complicated. Living under an oppressive military force, being exposed results not only in humiliation or discrimination, but also in becoming unreliable and suspicious in front of the leaders of the Communist Party. Also, because of the political atmosphere, Aliide - as many others - is being monitored all the time. Thus, besides controlling the target of her gaze, she also tries to hide from the gazes of the people around her, most particularly the ones who share her fate. She recognizes and avoids the women who are most likely the victims of violence, because she is afraid that outsiders would find their behaviours identical. 


\begin{abstract}
"When she found herself in proximity with one of those women, she tried to stay as far away from her as she could. So no one would notice the similarities in their behaviour. So they wouldn't repeat each other's gestures and double the power of their nervous presence." (OKSANEN 2011:168.)
\end{abstract}

As a result of her fear, she tries to go to public places as little as possible and organizes her life around her house, far from other people's inquisitive eyes.

\title{
FAKE IDENTITIES AS THE METHOD OF SELF-DEFENSE
}

In severe cases, when victims embody shame and the feeling of inferiority becomes a part of their identities, the urge of purifying or cleansing the body and hiding the source of shame merges into a third technique, which is basically a form of dissociation. This term can refer to the way our brain filters the memories, closes up the disturbing ones in the subconscious and makes them inaccessible for the victim. Dissociation can also mean a state of mind in which a victim leaves her body and sees events from an outsider's point of view to decrease the pain and fear (Herman 2011:60-66). In cases when the feeling of inferiority is too strong, people tend to use an interesting form of dissociation: they close up their real identities stained by a shameful past and create for themselves a new personality which they can proudly show society. In Oksanen's historical novels, dissociation has a very important role and it follows that almost all her protagonists possess a dual personality and use a fake identity as a method of self-defense.

For characters living in the communist era, besides the personal characteristics, fake identities always have a political dimension, too. The core element of their transformation is a change in the ideology; however, this inevitably reflects in their appearance as well.

In Purge, Aliide is intimidated, interrogated and finally raped because she is suspected of protecting and supporting her brother-in-law, who is clearly against the new political system. In order to prevent another humiliating night in the City Hall with the soldiers, Aliide decides to assimilate the new ideology and become a good communist herself. She changes her clothing and forms new habits to look like any other member of the working class. It can be mentioned as an example how she picks up the Soviet soldiers' style of drinking vodka. To guarantee her safety, she also marries a faithful Party member, Martin, even though the man disgusts her. Martin Truu smells, his smell sticks to Aliide, and she wears it as a shield, but also as a sign of changing alliances.

\footnotetext{
"In the mornings, the smell of Martin's armpits stuck to Aliide's hair and skin, his smell was in her nose all day long. He liked to sleep in a tight embrace, with his little mushroom Aliide tucked tightly under his arms. It was good; it gave her a feeling of security. [...] Nobody could have pulled her out from under that arm. [...] Ingel had said that Aliide was starting to smell like a Russian.” (OKSANEN 2011:171-172.)
}

In the third part of the Quartet series, When the Doves Disappeared, Oksanen follows the life of a married couple and pictures their transformations, which are triggered by the changes of politics and, in the woman's case, love.

Edgar Parts is a master of creating identities. As different forces occupy Estonia, dragging their ideologies with them, he changes names and identities as his interests 
dictate among changing political orders. He is always aiming at creating a personality that is the most acceptable to those in power. Although he cannot realize it, the feeling of inferiority has a strong influence on his opportunistic behaviour. Edgar is the opposite of the male ideal of wartime. He cannot stand violence or blood, and his feminine features make him soft. Moreover, he is drawn to other men. Edgar's society clearly considers homosexuality shameful, and in the atmosphere of the war and different kinds of resistance movements in Estonia, Edgar's personality and qualities would be disdained. To avoid humiliation, he is ready to do anything or betray anyone.

$\mathrm{He}$ is a master of words and faking, but he also shapes his appearance to fit his new character. Edgar is conscious about his looks and knows how to use them. Different clothes, hairstyles and strictly elaborated gestures are all parts of his play and his success. The following passage shows how he practices using his left hand instead of the right to create a more credible picture of the man he copies.

"He [Edgar] stood in his dark suit in front of the wardrobe mirror. Fervent, but controlled, he raised his arm, counted to three, let it fall, then repeated the gesture again [...] checking the angle of his arm [...] He'd secretly practiced a little in the woods, too, when he had the chance, taking care to remember from the outset that Eggert Fürst was left-handed.” (OKSANEN 2015a: 52.)

On the other hand, Edgar's wife, Juudit suffers from the feeling of inferiority because of her husband's behaviour. Although they are married, Edgar rejects Juudit as a woman and never touches her. Unable to understand the situation, she searches for the reasons of her unsuccessful marriage in her personality, and most particularly in her appearance. She starts to use a wide range of beauty practices to make herself more beautiful, but every failed attempt of intimacy strengthens her shame. Trapped in a non-functioning marriage with Edgar, and craving for happiness, when Edgar disappears during the war, Juudit falls in love with a German officer.

For Juudit, beauty practices are means of fulfilling others' expectations. Having a perfect body is essential for her, as she thinks, to become acceptable for Hellmuth, and thus to ensure not only love, but also a safer, better life for herself:

\footnotetext{
“Juudit couldn't afford to have varicose veins, couldn't afford to lose Hellmuth's interest, his fingers that crept up her legs in the darkness of the Estonia Theater. Hellmuth's worries had grown with his transfer. He had a longer trip to the offices in the economic division and missed working in his own area of expertise. There was a hollowness in his touch now, and this worried Juudit more and more each day, frightened her into taking greater care of her beauty. Her life depended on Hellmuth's feelings for her. Without them she had nothing." (OKSANEN 2015a:148-149.)
}

However, she cannot be unconditionally accepted in this relationship either. As a partner of Hellmuth Hertz, her feeling of inferiority has racial reasons, because as an Estonian she can never be as valuable as a German woman would be.

Preserving her beauty and changing her brown and curly hair and into blond and wavy are tools for Juudit to become acceptable by a German officer's side even if she is not of Aryan descent. She also starts dressing like the lovers of other soldiers and acting like the members of the groups belonging to the German order. On the other hand, her looks reflect her inner feelings, too: 


\begin{abstract}
"Nerves show immediately in a woman's skin, that's what Gerda would have said, and Juudit couldn't afford to let them show. She started by lathering up her shaving soap. She'd learned from Gerda that you can only get really smooth legs with a razor, not with hydrogen sulfide, which stank in any case. The tan on Juudit's legs was weak, pale. She ought to do something about that. After her bath she sprinkled salicylic powder under her arms and put the can back on the shelf next to the black pen she'd used to use to draw seams along the backs of her legs in her stockingless days. Her darkened elbows showed in the mirror like storm clouds. She picked up the hand mirror and tried to see how bad they were. She should have the maid bring more lemons. Other than that, her transformation from dove soft to scaly snake didn't show. Or was she just fooling herself?" (OKSANEN 2015a:149.)
\end{abstract}

When she unwillingly agrees to the demand of Roland, a fighter of free Estonia, to help those Jews and Estonians who want to flee the German rule, she is anxious that her disloyalty to Hellmuth will show in her looks. Interestingly, Roland associates Juudit's made-up face with lies and betrayal against the interests of her own people - i.e. both Estonians and friends, such as him:

"I relished the idea of sending my men after Juudit, frightening her. [...] I imagined the look of shock on her face, how her head would sink into her fox collar, how her mouth, painted with lipstick and deceit, would disappear into the fur." (OKSANEN 2015a:109.)

This recalls the Kapitánys' claim (KAPITÁNY - KAPITÁNY 2009:22-23) that, based on the Christian duality of mind and body, in Medieval Europe caring too much for personal hygiene was interpreted as undervaluing the importance of the purity of the mind, and thus resulting in depravity.

All the descriptions of Juudit's beauty tricks strengthen later the effect of her caring no more for even personal hygiene, as a sign of her inner breakdown:

"She had changed radically — she'd started missing days at work early; the smell of liquor had seeped into the wallpaper; her appearance, which she had always taken care of before, had fallen away curl by curl, her skin graying as quickly as the women's hair covered in ash after the bombings." (OKSANEN 2015a:82.)

Personal and beauty care come up in different ways in Sofi Oksanen's novels, and have varying symbolic meanings, but there is at least one thing in common: they are related to creating a false identity, one which is more acceptible for those around. This is in parallel with what the Kapitánys say (KAPITÁNY - KAPITÁNY 2009:28-29) on the connection between how individuals think about cleanliness and what is the relationship between society and the individuals. They claim that the more hierarchical structure a society has, the greater importance appearances may have in it, i.e. the members of the society try to fulfill the expectations of the Whole, or of the Supremacy representing it. When social hierarchy subordinates a self-organized, traditional community, behaving as a member of the community changes into behaving as a subject. Individuals still try to fulfill expectations, but no longer those of a general power that they themselves belong to, but those of an outer or upper power. This results in the separation of appearances and reality. Meeting the expectations becomes important only when and where it is visible to 
others. A good example of this is the make-up scene from Baby Jane, where the narrator is constructing a beautiful face visible to others, while she is smoking one cigarette after the other, polluting her body from inside.

The narrator-protagonist of Baby Jane is a young woman suffering from severe depression. It is vital to her that things happen as she is used to them, otherwise she is unable to perform even everyday acts - e.g. she cannot leave home when she has run out of cotton swabs and she cannot do her make-up as her routine dictates. As a lesbian, she belongs to the type femme, meaning that her style is emphatically feminine. When her relationship with Piki ends in a painful way, she chooses to live with a man so that she could be the furthest possible away from the world associated with her former lover. This is a life of pretense: she is faking heterosexuality to be in love with Joonatan, to belong to the group of healthy, busy, successful people. She spends her days in exactly the same way: wakes up when her partner does, pretends that she is also preparing for the day, and when the man leaves, goes back to sleep or to take a bath.

\begin{abstract}
"After the day cream, I applied primer and let it sink in. I smoked a cigarette. I brightened my eyes with more eyedrops and took the foundation, which I spread carefully with the sponge, and blended it towards my neck. I added cream blush to the dimple that appears when I pull my cheeks in, and dusted my faces with loose powder and a velvet brush. I smoked another cigarette. I applied eyeshadow primer, spread dark eyeshadow into the outer and light one into the inner corners, then rimmed my eyes with wet eye liner and blended the rim with the foam rubber end of the liner pencil. I added some more eye liner to the inner eyelids, and finished the make-up of my eyes with waterproof mascara. After applying primer to my lips, I rimmed them with a lip pencil, applied extra longwear lipstick with a brush, powdered my lips, added some more lipstick, and mopped them up with a sheet of blotting paper. And then some lustre to the brow bones and to the cheekbones. Now that I am still young enough to use it, I have to take the most out of it. Before moving on to choose my clothing, I went and made some more coffee." ${ }^{4}$ (OKSANEN 2009:53.)
\end{abstract}

The fact that every small detail of this morning preparation is mentioned underlines their importance: it is vital to the character that she could do her make-up in the usual way. It also emphasizes the overall importance of her make-up: what we can see here is the construction of a false appearance, one that is associated with normal, successful people. The perfect beauty of this constructed face and the meticulous description of the process are in a sharp contrast with the narrator's inner self: she is broken down and has no meaning in her life.

Creating an ideal appearance is vital for the main protagonist of Stalin's Cows, too. Although Anna does not live in the communist era any more, she inherits the shame of her mother, which is clearly the product of the former political system. As was stated before, Anna is ashamed of her Estonian roots, and is afraid that she would not be accepted in the Finnish society as a daughter of an Estonian mother. On the other hand, as an only child, she is very spoiled and used to attention, so she has never considered hiding, as Aliide did. The eating disorders have an objective of creating a perfect body, which gives

\footnotetext{
${ }^{4}$ Translation by Laura Bába.
} 
Anna the admiration of others and, at the same time, functions as a disguise and hides her true identity. However, Anna's behaviour is very paradoxical, because she hides the secret of her roots very carefully on the one hand, but on the other she constantly risks being exposed by following the dressing and make-up style of the Russian and Estonian women she saw and admired in Tallinn as a child. It is also interesting how she alternates her outfits and accessories: she uses both the sportier look of the Finnish and the clearly more feminine style of the Estonian women, depending on where she is. This transformation is also influenced by the political changes and has roots in Anna's childhood, while it loses most of its meaning in society during the 1990s, and only remains important to Anna herself.

While Anna tries to become invisible and merge with the crowd, she is also striving for visibility and acceptance. Anna decides to create a perfect body, to give a new reason why others look at her, instead of her Estonian origin. This recalls Bourdieu's thoughts (BOURDIEU [2008]:110-111) on how people relate to the socially constructed image of their body. If there is no balance between the original qualities and abilities of someone and the social concept of legitimate appearances and conduct, they will feel strained about their body or their manner of speaking. They think that these betray their origin, and, consequently, they do not identify with them but look at them as from the outside, through the eyes of the others. This results in overcompensation: in a constant effort to regain rule over their body, they are controlling and correcting it, and thus they are exposing it to expropriation. This can be detected in the fact that the body Anna is striving to attain matches the one that is associated with the identity she wants to escape: in Finland, Estonian women are taken as prostitutes, and the latter are associated with extremely feminine style, yet while Anna is hiding her Estonian origin, she is aspiring for a very womanly body and manner.

However, an important part of Anna's struggle is that by taking control over her body, it is she who decides over herself and not others. Control is vital to Anna: she has grown up to know no moderation, because, as she thought, in Finland she had nothing while in Estonia she got everything (e.g. her mother could not afford to buy her sweets in Finland, so she bought her all the sweets in Estonia). This is why Anna does not know anything about what she would like to do or have. Instead, she acts on decision - both in connection with eating and vomiting as well as with her relationships. She wants to maintain this control to the utmost end. When she catches herself dissolving into a relationship, feeling safe and getting more and more negligent about her looks - she takes the habit of leaning on her elbows, even if they get wrinkled and black, or the habit of sitting on her thighs, even if this causes cellulite - she then decides to alienate herself from the man in order to avoid a complete loss of control, which would mean telling him about her Estonian origin. It would also mean losing her Lord, as she calls her eating disorder, which would result in her size getting enormous. At this point, she cannot permit herself any of these.

\section{RELEASING SHAME - ATTEMPTS AT HEALING}

Anna is a special character in the Quartet novels, not only because she lives after that historical era which forces the other characters of the series to change their lifestyles, but also because - partly due to the increased range of freedom in the new system - she finds 
the roots of her shame and realizes the emptiness behind her fake identity. In order to free herself from the distress, Anna starts talking about Estonia and her relationship to it, and realizes that society does not consider it shameful at all. However, it is not enough to put an end to the eating disorders, because the feeling of inferiority is too deeply embedded and it is an inseparable part of her identity. As she learns to identify her feelings, she also manages to control the physical symptoms, but cannot leave them behind.

There is one more character in Oksanen's novels who tries to get rid of shame: Aliide Truu in Purge. Her being the only one besides Anna to attempt to reach freedom is very interesting and surprising at the same time, as she is the one who is under the strongest control and dependence because of the place and times she lives in, and also because of the nature of her traumatic experiences. In her fight to neutralize shame and live a normal life, the meaning of eye contact becomes important again. Aliide plans to escape to Tallinn with Hans, whom she hides in their house for years. As she had experienced all kinds of suffering for the sake of her brother-in-law, she feels that if she could gain his love and acceptance, it would give meaning to the horrors of her life. Aliide uses Ingel's beauty practices to make herself similar to her, or even better, and hopes she can awaken Hans' interest and make him look at her and see her true self. Ingel has always been a mistress of household and beauty practices, Aliide has always lagged behind - nor even wanted to do things as Ingel did. Now she starts to adapt her sister's tricks to fulfill what she thinks Hans' expectations are:

"She fixed her hair, pinched her cheeks, brushed her teeth with charcoal, and rinsed them for a long time. It was a trick of Ingel's - that's why her teeth were always so white. Aliide hadn't wanted to imitate Ingel too much before, so she had always done without the charcoal. But things were different now." (OKSANEN 2011:200.)

However, Aliide's tragedy is that Hans never realizes what kind of sacrifices she has made for him. During the peaceful times he always looks at Ingel, even when he dances with the younger sister, and finally, before his death, driven crazy by years of hiding, he talks to an imagined figure of his wife and never ever looks Aliide in the eye. It follows that Aliide can never be released from the feeling of inferiority which her sister's greatness caused her; however, she finds meaning in her traumas by saving Zara at the end.

\section{CONCLUSION}

The examples found in the Quartet series and Baby Jane show how the shame of inferiority influences our minds, and through it also our bodies. Oksanen pictures the most common bodily responses for embodied shame very objectively. The uncontrollable nature of these physical responses points out that because of biological laws we cannot free ourselves from the consequences of the affect mechanism. The change should happen in society, which should not link the feeling of inferiority to the automatic reactions of shame in order to use it for gaining control over certain groups of people. It is also important to state that everyone has an important role in easing the victims' suffering from symptoms caused by the feeling of inferiority by creating a more empathic social space, where their shame can turn into the pride of survivors. 


\section{LITERATURE}

\section{OKSANEN, Sofi}

2003 Stalinin lehmät [Stalin's Cows]. Helsinki: WSOY.

2005 Baby Jane. Helsinki: WSOY.

2008 Puhdistus [Purge]. Helsinki: WSOY.

2009 Baby Jane. (5 ${ }^{\text {th }}$ edition), Helsinki: WSOY.

2010 Purge. (Translation by Lola Rogers), New York: Grove/Atlantic, Black Cat; London: Atlantic Book.

2011 Purge. (Translation by Lola Rogers), paperback edition, London: Atlantic Book.

2012 Kun kyyhkyset katosivat [When the Doves Disappeared]. Helsinki: Like.

2015a When the Doves Disappeared. (Translation by Lola Rogers), London: Atlantic Books.

2015b Norma. Helsinki: Like.

\section{REFERENCES CITED}

Bourdieu, Pierre

[2008]Hevenyészett megjegyzések a test társadalmiészleléséröl[Preliminary Remarks on the Social Perception of the Body]. In A társadalmi egyenlötlenségek újratermelödése. Tanulmányok [The Reproduction of Social Inequalities. Essays]. $2^{\text {nd }}$ edition, 108-117. Budapest: General Press.

HERMAN, Judith Lewis

2011 Trauma és gyógyulás. Az erőszak hatása a családon belüli bántalmazástól a politikai terrorig [Trauma and Recovery. The Effect of Violence from Domestic Abuse to Political Terror]. Budapest: Háttér - NANE egyesület.

KAPITÁNY, Ágnes - KAPITÁNY, Gábor

2009 Néhány gondolat a tisztaság szimbolikájáról [Some Thoughts upon the Symbolics of Cleanliness]. In JuHász, Katalin (ed) Tiszta sorok: Tanulmányok a tisztaságról és a tisztálkodásról [Clean(/r) Lines: Essays on Cleanliness and Grooming], 17-47. Documentatio Ethnographica 25. [Budapest:] L'Harmattan.

KLINGMAN, Gail - Limoncelli, Stephanie

2005 Trafficking Women after Socialism. From, To and Through Eastern Europe. Social Politics 12(1):118-140.

LaPPALAINEN, Päivi

2011 Häpeä, ruumis ja väkivalta Sofi Oksasen Puhdistuksessa [Shame, the Body and Violence in Sofi Oksanen's Purge]. In Kainulainen, Siru - ParenteČAPKOvá, Viola (eds) Häpeä vähän! Kriittisiä tutkimuksia häpeästä [Shame on you! Critical Essays on Shame]. Turku: UTU. 
2013 Finnish Literature Abroad - The Case of Purge by Sofi Oksanen. In Järventausta, Marja - PAntermöller, Marko (eds): Finnische Sprache, Literatur und Kultur im deutschsprachigen Raum [Finnish Language, Literature and Culture in German-Speaking Areas], Wiesbaden: Harrassowitz. LuIG, Judith (Veröffentlichungen der Societas Uralo-Altaica. Band 85, 333-351.)

2010 Im Fegefeuer der Geschichte. (In the Purgatory of History) Die Welt 21.09.2010. http://www.welt.de/welt_print/kultur/article9770740/Im-Fegefeuer-derGeschichte.html [accessed September 15, 2015]

Probyn, Elspeth

2005 Blush. Faces of Shame. Minneapolis - London: University of Minnesota Press. ToMkins, Silvan S.

1987 Shame, In Nathanson, Donald L. (ed) The Many Faces of Shame. 133-161. New York: Guilford.

Laura Bába, PhD, is a lecturer at the Department of Finno-Ugric Studies at Eötvös Loránd University (Budapest). She wrote her PhD thesis on eating disorders as a literary subject in contemporary Finnish youth novels (2012, Eötvös Loránd University). She is also a translator of Finnish literature into Hungarian, her translations include some of Sofi Oksanen's novels (Baby Jane, Kun kyyhkyset katosivat and Norma). Email-address: baba.laura@btk.elte.hu

Krisztina, Karizs is an Assistant Professor at Hankuk University of Foreign Studies, where she teaches Hungarian and Finnish. Karizs works as an editor for the journal of the University of Jyväskylä, Spectrum Hungarologicum, and has served as technical editor on several projects. Her past experience includes six months teaching Hungarian language and culture at the University of Jyväskylä in Finland and three years teaching Hungarian and Finnish language at the Hankuk University of Foreign Studies in South Korea. Karizs has written extensively on contemporary Finnish and Hungarian literature and her research focuses on social problems such as discrimination, violence against women, and the consequences of traumas. She is also interested in psychiatry and memory studies and applies its perspective and concepts to her work. Email-address: sevenke@gmail.com 